\title{
PERANAN DESA WISATA DALAM PEMBANGUNAN DESA DI DESA MUN- DUK KECAMATAN BANJAR KABUPATEN BULELENG
}

\author{
Ni Wayan Sutiani \\ Fakultas Ilmu Sosial dan Ilmu Politik, Universitas Mahendradatta Denpasar \\ e-mailssutianiwayan12@gmail.com
}

\begin{abstract}
Abstrak - Kabupaten Buleleng merupakan satu dari delapan kabupaten di Bali yang dikenal oleh wisatawan mancanegara sebagai destinasi wisata yang menarik, dimana daerah tersebut memiliki bermacam seni, kebudayaan, dan daya tarik wisata alam. Desa Munduk memiliki bermacam tourist attraction yang terdiri atas kesenian atau budaya dan pemandangan alam, berupa perbukitan, persawahan, dan air terjun yang menjadi ciri khas di desa tersebut. Konsep Tri Hita Karana merupakan landasan dalam menjalani kehidupan sehari-hari masyarakat lokal di Desa Munduk. Desa wisata merupakan suatu bentuk integrasi antara atraksi, akomodasi dan fasilitas pendukung yang disajikan dalam suatu struktur kehidupan masyarakat yang menyatu dengan tata cara dan tradisi yang berlaku dimana wisatawan dapat tinggal di dalam atau dekat dengan desa tersebut untuk mempelajari dan menikmati kehidupan di desa tersebut.

Dari uraian latar belakang di atas, maka perumusan masalah dalam tulisan ini adalah: bagaimanakah peranan desa wisata dalam pembangunan desa di Desa Munduk, Kecamatan Banjar Kabupaten Buleleng. Metode penelitian yang dilakukan dengan menggunakan wawancara.

Simpulan dari hasil penelitian menunjukkan bahwa peranan desa wisata munduk di Desa Munduk Kecamatan Banjar Kabupaten Buleleng adalah sebagai sumber penghasilan bagi masyarakat di Desa Munduk selain sebagai petani mengingat wilayah desa Munduk sebagai desa wisata yang banyak dikunjungi oleh wisatawan yang pada akhirnya dapat menambah penghasilan masyarakat sekitar. Adapun saran yang dapat diajukan adalah: Bagi pemerintah desa Munduk hendaknya dapat mendukung desa wisata di Munduk dengan membantu pemberian fasilitas pendanaan bagi pengembangan agar dapat berkembang. Selain itu masyarakat diberikan kemudahan untuk permodalan dalam rangka membangun usaha untuk mendukung desa wisata di desa Munduk Kecamatan Banjar Kabupaten Buleleng.
\end{abstract}

Kata kunci: desa wisata, pembangunan desa

\begin{abstract}
Abstrak - Buleleng Regency is one of eight regencies in Bali that is known by foreign tourists as an attractive tourist destination, where the area has a variety of arts, culture and natural tourist attractions. Munduk Village has a variety of tourist attractions consisting of arts or culture and natural scenery, in the form of hills, rice fields, and waterfalls that are characteristic of the village. The concept of Tri Hita Karana is the basis for living the daily lives of local people in Munduk Village. Village tourism is a form of integration between attractions, accommodation and supporting facilities that are presented in a structure of community life that integrates with the prevailing procedures and traditions where tourists can stay in or close to the village to learn and enjoy life in the village.

From the description of the background above, the formulation of the problem in this paper is: what is the role of tourism villages in the development of villages in Munduk Village, Banjar District, Buleleng Regency. The research method is done using interviews.

Conclusions from the results of the study indicate that the role of the tourist village munduk in Munduk Village, Banjar Subdistrict, Buleleng Regency is as a source of income for the people in Munduk Village other than as farmers, considering the Munduk village area as a tourist village that is visited by many tourists which in turn can increase the income of the surrounding community. The suggestions that can be asked are: For the Munduk village government should be able to support tourism villages in Munduk by helping to provide funding facilities for development in order to develop. In addition, the community is given facilities for capital in order to build a business to support tourist villages in the village of Munduk, Banjar District, Buleleng Regency.
\end{abstract}

Keywords: Tourism Village, Village Development 


\section{Pendahuluan}

Pada saat ini kepariwisataan di Indonesia telah tumbuh dan berkembang menjadi salah satu pemasukan devisa bagi negara. Hal tersebut dapat terjadi karena Indonesia memiliki potensi yang besar di sektor pariwisata. Ini bisa dilihat dari indahnya berbagai macam pemandangan alam, kebudayaan, sejarah bangsa, festival- festival atau upacara-upacara daerah yang unik, berbagai macam seni lukis, kerajinan tangan, dan banyaknya tempat yang sangat menarik bagi para wisatawan mancanegara yang ingin mengunjungi destinasi wisata di setiap daerahnya.

Bali merupakan salah satu destinasi pariwisata terbaik di Indonesia, dimana terdapat berbagai potensi wisata. Melihat potensi yang dimiliki Bali dari keindahan alam, keramah-tamahan penduduk, seni budaya dan adat-istiadatnya yang khas, membuat sektor pariwisata mendapat perhatian yang khusus dan serius dari pemerintah daerah Provinsi Bali. Banyaknya kunjungan wisatawan baik dari luar maupun dalam negeri yang datang, membuat industri-industri di bidang pariwisata bermunculan seperti hotel, biro perjalanan wisata, restoran, SPA, dan lain-lain. Tentunya hal ini adalah peluang yang sangat besar bagi para pengusaha asing ataupun lokal untuk berlomba dalam meraih keuntungan besar di sektor pariwisata.

Kabupaten Buleleng merupakan satu dari delapan kabupaten di Bali yang dikenal oleh wisatawan mancanegara sebagai destinasi wisata yang menarik, dimana daerah tersebut memiliki bermacam seni, kebudayaan, dan daya tarik wisata alam. Pembangunan sarana dan prasarana juga terus dilakukan oleh pemerintah daerah, masyarakat lokal, dan para pengusaha.

Wilayah Kabupaten Buleleng dibagi menjadi sembilan kecamatan, yaitu kecamatan Banjar, Buleleng, Busungbiu, Gerokgak, Kubutambahan, Sawan, Seririt, Sukasada, dan Tejakula. Kecamatan Banjar sendiri terdiri dari banyak kelurahan atau desa, salah satunya yaitu Desa Munduk. Desa tersebut dapat ditempuh sekitar dua jam dari Denpasar, dengan menggunakan kendaraan bermotor dan mobil. Masyarakat lokal di Desa Munduk sebagian besar bermata pencaharian sebagai petani, pedagang, pekerja di industri pariwisata seperti home stay, SPA, dan restoran.
Desa Munduk memiliki bermacam tourist attraction yang terdiri atas kesenian atau budaya dan pemandangan alam, berupa perbukitan, persawahan, dan air terjun yang menjadi ciri khas di desa tersebut. Akses jalan untuk dapat berkunjung ke Desa Munduk juga sudah banyak mengalami perbaikan, sehingga tentunya dapat memudahkan wisatawan yang ingin datang untuk menikmati pemandangan alam dan budaya di Desa Munduk. Lokasi desa tersebut berada di kawasan yang strategis, akses atau jalur untuk menuju ke Desa Munduk juga merupakan salah satu jalur alternatif atau jalur penghubung bagi wisatawan yang ingin mengunjungi objek wisata yang ada di kawasan Bedugul dengan objek wisata Pantai Lovina. Adapun jumlah kunjungan wisatawan ke Desa Munduk dalam lima tahun terakhir, dapat dilihat pada Tabel 1 berikut

\begin{tabular}{|l|l|l|l|l|l|}
\hline \multirow{2}{*}{ No } & Thn & \multicolumn{2}{|c|}{ Wisatawan } & Jumlah & Pertumb \\
\cline { 3 - 4 } & & Domst & Mancngr & & \\
\hline 1 & 2013 & 4.514 & 16.807 & 21.321 & $6,80 \%$ \\
\hline 2 & 2014 & 4.034 & 21.108 & 25.142 & $17,92 \%$ \\
\hline 3 & 2015 & 1.417 & 20.432 & 21.849 & $(-13,09 \%)$ \\
\hline 4 & 2016 & 4.585 & 21.659 & 26.244 & $20,11 \%$ \\
\hline 5 & 2017 & 5.012 & 23.678 & 28.690 & $9,32 \%$ \\
\hline Total & 19.562 & 103.684 & 123.246 & $41,05 \%$ \\
\hline \multicolumn{2}{l|}{ Rata2 } & 3.912 & 20.736 & 24.649 & $8,21 \%$ \\
\hline
\end{tabular}

Sumber data: kunjungan wisatawan Desa Munduk, tahun 2017

Berdasarkan data jumlah kunjungan wisatawan ke Desa Munduk di atas, dapat dilihat bahwa jumlah kunjungan wisatawan baik itu domestik dan mancanegara yang juga didominasi oleh wisatawan yang berasal dari Negara Belanda, Prancis, Jerman, Denmark, dan Australia terus mengalami peningkatan pada tahun 2012 hingga 2013. Pada tahun 2014 jumlah kedatangan wisatawan ke Desa Munduk mengalami penurunan sebesar 3.293 wisatawan, dikarenakan bencana alam yang menyebabkan akses menuju Desa Munduk ditutup. Pada tahun 2015 dan 2016, jumlah kunjungan wisatawan ke Desa Munduk kembali meningkat. Kembali meningkatnya kunjungan wisatawan mancanegara ke Desa Munduk merupakan hal positif dan tentunya peluang besar yang harus dimanfaatkan masyarakat lokal dengan baik.

Desa Munduk juga memiliki potensi yang besar di sektor pariwisata, namun hal tersebut kurang dimanfaatkan dengan baik oleh masyarakat lokal. Potensi alam 
yang terdapat di desa tersebut tentunya akan mampu memberikan efek positif terhadap perekonomian masyarakat sekitar. Perkembangan industri pariwisata di Desa Munduk, seperti home stay, SPA, dan restoran, harus diimbangi dengan pemanfaatan potensi alam yang dikelola secara baik, sehingga terciptanya pariwisata yang berkelanjutan.

Konsep Tri Hita Karana merupakan landasan dalam menjalani kehidupan sehari-hari masyarakat lokal di Desa Munduk. Hal itu dapat dilihat dari bagaimana masyarakat menjaga hubungan dengan $\mathrm{Tu}-$ han, sesama manusia, dan alam. Namun seiring berkembangnya pariwisata di Desa Munduk, membuat kesadaran masyarakat sedikit berkurang, khususnya dalam hal menjaga dan merawat alam.

Konsep desa wisata pada awalnya diartikan secara sederhana, yakni melakukan kegiatan wisata di desa. Namun demikian konsep desa wisata tidak sesederhana demikian. Desa wisata merupakan suatu bentuk integrasi antara atraksi, akomodasi dan fasilitas pendukung yang disajikan dalam suatu struktur kehidupan masyarakat yang menyatu dengan tata cara dan tradisi yang berlaku dimana wisatawan dapat tinggal di dalam atau dekat dengan desa tersebut untuk mempelajari dan menikmati kehidupan di desa tersebut.

Prinsip pengembangan desa wisata : (i) memanfaatkan sarana dan prasarana masyarakat setempat, (ii) menguntungkan masyarakat setempat, (iii) berskala kecil untuk memudahkan hubungan timbal balik dengan masyarakat setempat, (iv) melibatkan masyarakat setempat. Dalam menerapkan pengembangan produk wisata pedesaan konsep desa wisata sangat memperhatikan hal-hal sebagai berikut : (i) Penyediaan fasilitas dan prasarana yang dimiliki masyarakat lokal yang biasanya mendorong peran serta masyarakat dan menjamin adanya akses ke sumber fisik merupakan batu loncatan untuk berkembangnya desa wisata, (ii) mendorong peningkatan pendapatan dari sektor pertanian dan kegiatan ekonomi tradisional lainnya,(iii) penduduk setempat memiliki peranan yang efektif dalam proses pembuatan keputusan tentang bentuk pariwisata yang memanfaatkan kawasan lingkungan dan penduduk setempat memperoleh pembagian pendapatan yang pantas dari kegiatan pariwisata, (iv) mendorong perkembangan kewirausahaan masyarakat setempat. Salah satu lokasi di Bali Utara, yang menyimpan potensi begitu besar, namun belum dikenal dunia. Namanya Desa Munduk, berada di Kabupaten Buleleng . Berada di kawasan pegunungan membuat desa ini memiliki udara sejuk. Hamparan kebun dan hutan menghadirkan pemandangan indah. Apalagi, Munduk memang dikenal sebagai salah satu daerah utama penghasil cengkeh dan kopi di Bali.

Dari uraian latar belakang masalah dapat dirumuskan permasalahan sebagai berikut: bagaimanakah peranan desa wisata dalam pembangunan desa di Desa Munduk, Kecamatan Banjar Kabupaten Buleleng?

\section{Metode Penulisan}

Metode penelitian yang dilakukan dengan menggunakan wawancara. Yang dimaksud dengan wawancara menurut Nazir (2005) adalah proses memperoleh keterangan untuk tujuan penelitian dengan cara tanya jawab sambil bertatap muka antara si penanya atau pewawancara dengan si penjawab atau responden dengan menggunakan alat yang dinamakan interview guide (panduan wawancara).

Selain istilah wawancara dalam keseharian kita juga sering menjumpai istilah "ngobrol" atau percakapan. Berkaitan dengan istilah tersebut Irawati S. dalam Masri Singarimbun (2008) memberikan garis pembeda antara wawancara dengan percakapan. Pada wawancara; pertama, pewawancara belum saling mengenal responden (yang diwawancarai), sedangkan percakapan biasanya sudah saling mengenal. Kedua, pewawancara adalah pihak yang terus-menerus bertanya, sedangkan responden pihak yang selalu menjawab pertanyaan tersebut. Sedangkan percakapan saling bertanya, saling menjawab bahkan saling menimpali begitu saja. Ketiga, urutan pertanyaan sudah ditentukan. Sedangkan percakapan tema yang dibicarakan bisa berubah-ubah bahkan dalam waktu seketika.

Metode wawancara adalah suatu metode pengumpulan data dengan cara melakukan tanya jawab yang sistematis, dan hasil tanya jawab ini dicatat/direkam secara cermat (Agung, 2012:7). Tanya jawab 'sepihak' berarti bahwa pengumpul 
data yang aktif bertanya, sermentara pihak yang ditanya aktif memberikan jawaban atau tanggapan. Dari definisi itu, kita juga dapat mengetahui bahwa Tanya jawab dilakukan secara sistematis, telah terencana, dan mengacu pada tujuan penelitian yang dilakukan.

\section{Pembahasan}

\section{Sejarah Desa Munduk}

Pada awalnya Desa Munduk Bestala berstatus sebagai Banjar Dinas yang merupakan bagian dari wilayah Pemerintahan Administrasi Desa Banyuseri dan secara Adat sebagai bagian Desa Adat Bastala. Keberadaan demikian disebabkan karena orang -orang (penduduk ) Munduk Bestala pada waktu itu adalah anggota masyarakat Desa Bestala yang menempati tanah (kebun - kebun) yang merupakan bagian wilayah Desa Banyuseri Kecamatan Banjar, sehingga penduduk Munduk Bestala menanggung dan menjalani dua (2) peran aktifitas pemerintahan. Sementara itu aktifitas kemasyarakatan Munduk Bestala banyak berorientasi ke pemerintahan Adat Desa Bestala. Hal ini berlangsung sampai tahun 1952.

Awal mula terjadinya Pemekaran Status Desa. Selama dalam perjalanan sejarah pemerintahan Banjar Munduk Bestala sering menghadapi kendala dan permasalahan. Antara lain yaitu adanya ketidakseimbangan yang sangat menonjol antara kewajiban melaksanakan pembangunan dengan hasil pembangunan atau hak yang seharusnya diperoleh penduduk Munduk Bestala. Salah satu diantaranya dapat dilihat dari peristiwa perampokan pada tahun 1940 yang menimpa salah seorang warganya ( Wayan Winarsa ). Kejadian ini sempat di laporkan kepada Kepala Desa Bestala, namun ironisnya hal tersebut tidak mendapat tanggapan dari pihak pemerintah Desa Bestala. Hal yang sama terulang ketika laporan ini juga di laporkan kepada Kepala Desa Banyuseri. Tidak ada tanggapan yang di dapat. Namun persoalan ini rupanya tidak dibiarkan berlarut, oleh Kelian Banjar yang waktu itu di jabat oleh I Wayan Wenten (almarhum), peristiwa perampokan yang menimpa warga Munduk Bestala akhirnya dilaporkan langsung ke Camat Banjar yang pada saat itu masih berstatus Ponggawa dan langsung mendapat tanggapan yang serius.
Berangkat dari pengalaman peristiwa perampokan tersebutlah, Banjar Munduk Bestala sering mengadakan koordinasi langsung ke Camat (Ponggawa Banjar). Sebelum tahun 1953 Banjar Munduk Bestala sempat dipimpin oleh Pan Kerti (almarhum). Kemudian pada tahun 1953, Banjar Munduk Bestala mendapatkan status baru menjadi Banjar Langsung (bukan lagi status desa ) sehingga bisa langsung berhubungan dengan Camat Ponggawa. Selama sepuluh tahun menyandang sebagai Banjar Langsung kemudian statusnya meningkat menjadi Banjar Manca ( Banjar / Dusun Difinitif ) pada tahun 1963. Namun tidak berhenti sampai disini, berkat usaha yang berkelanjutan, warga Banjar Munduk Bestala melalui tokoh - tokoh Banjar yang dipimpin I Wayan Wenten (almarhum), terus mengadakan pendekatan kepada Camat (Ponggawa Banjar) meminta agar Banjar Munduk Bestala dapat membangun dan menikmati langsung hasil-hasil pembangunan yang dilaksanakan di Munduk Bestala.

Sementara menunggu keputusan resmi dari pemerintah, warga Munduk Bestala secara berangsur - rangsur mulai membangun sarana desa seperti : Pura Kahyangan Tiga, Kantor Perbekelan, serta pemakaman dan sarana penunjang lainnya. Kesemua itu dilaksanakan secara gotong royong oleh seluruh anggota masyarakat. Pada tahun 1966 atas perhatian yang sungguh - sungguh dari pihak pemerintah, maka resmilah Banjar Munduk Bestala menjadi status desa difinitif yaitu " Desa Munduk Bestala " yang langsung berada dibawah Kecamatan Banjar dengan tidak menuntut hak dan kewajiban atas andil yang tertanam di Desa Bestala.

Desa Munduk Bestala mengandung makna : Munduk berarti suatu tempat yang secara geografis letaknya lebih tinggi dari desa induk ( Bestala ), sedangkan nama Bestala diambil dari nama desa induk karena Desa Munduk Bestala merupakan hasil pemekaran dari Desa Bestala.

Seluruh wargapun menyambut peristiwa ini dengan antusia dan rasa syukur yang mendalam kehadapan Ida Sang Hyang Widhi Wasa. Status difinitif dibawah Kecamatan Banjar hanya berlangsung singkat, karena oleh perangkat Desa Munduk Bestala dirasakan bahwa segala urusan pemerintahan lebih mudah dan lebih dekat 
diurus di Kecamatan Seririt.

Atas dasar itulah, maka Perbekel

( Kepala Desa ) Desa Munduk Bestala kemudian mengajukan permohonan agar Desa Munduk Bestala dimasukkan dalam wilayah Kecamatam Seririt. Sehinga tahun 1967, Desa Munduk Bestala resmi menjadi bagian dari wilayah pemerintahan Kecamatan Seririt.

\section{Peran Desa Wisata dalam Pemban- gunan desa di Desa Munduk, Keca- matan Banjar Kabupaten Buleleng}

Selain mengandalkan sektor bercocok tanam, Munduk kini tengah digandrungi bisnis pariwisata. Kehadiran Cottage Puri Lumbung pada awal tahun 1990-an menandai dimulainya sektor pariwisata di Munduk. Dengan mengandalkan hamparan pohon cengkeh dan pegunungan yang ada, sektor wisata hutan mulai hidup.

Penginapan-penginapan dan restoran di sepanjang jalan mulai dibangun. Meski sudah ada penginapan yang dibangun pada 1992, namun hingga 2010, jumlahnya hanya sembilan. Dan kini, sudah ada sekitar 47 hotel dan restoran yang berdiri.

Desa ini mengandalkan hutan seluas 1056 hektar sebagai jualan utama. Keberadaan beberapa tempat wisata seperti Air Terjun Tanah Bara dan Air Terjun Melanting ikut menyemarakkan wisata tracking ala Munduk. Tak hanya itu, Munduk juga masih memiliki Danau Tamblingan yang juga dikelilingi oleh hamparan hutan yang asri, yang bernama Amerta Jati.

Meski mulai mengembangkan sektor pariwisata, Desa Munduk tetap menjaga perkebunan sebagai sektor utama ekonomi masyarakat. Karena memang keberadaan perkebunan dan hutan yang menjadi daya tarik wisatawan untuk datang ke desa tani ini.

Di kalangan wisatawan domestik memang Desa Munduk ini relatif kurang terkenal bahkan untuk orang Denpasar sekalipun, cukup banyak yang kurang begitu familiar bahwa desa ini punya potensi wisata. Namun tidak demikian bagi kalangan wisatawan asing khususnya Eropa, nama Munduk sudah tidaklah asing lagi. Desa Munduk menjadi pilihan bagi mereka yang berlibur ke Bali untuk memperoleh ketenangan dan keasrian alam Bali yang belum begitu banyak tersentuh modernisa- si.

Desa Munduk biasa dilewati wisatawan yang ingin berkunjung ke Pantai Lovina, Buleleng di Bali utara, pantai yang terkenal dengan atraksi lumba-lumbanya. Namun seiring berjalannya waktu, banyak juga wisatawan yang kepincut dengan keindahan dan suasana asri di Munduk hingga memilih bermalam.

Meskipun amat jauh jika dibandingkan fasilitas wisata di Bali selatan, secara umum fasilitas wisata yang ada cukup memadai bagi para pelancong. Penginapan di Desa Munduk umumnya berbentuk cottages atau pondok-pondok terpisah. Hal ini karena mereka menyesuaikan dengan lansekap Munduk yang berbukit-bukit naik turun. Apalagi jika mengingat 'jualan' utama Desa Munduk adalah keasrian dan alam yang alami atau dalam istilah kerennya eco-tourism. Tentu sebisa mungkin para pelaku pariwisata lokal ingin mempertahankan kondisi yang ada. Untuk itu, pengelola penginapan-penginapan di Desa Munduk membuatnya seperti menyatu dengan alam.

Semua penginapan tersebut menyediakan fasilitas sama, satu pondok terpisah (private cottage) dilengkapi air panas, TV, Wifi, serta dapur. Sangat memadai untuk ukuran wisata desa apalagi dengan tawaran harga yang cukup bersahabat. Kebanyakan pondok wisata juga memberikan balkon dengan pemandangan alam di depannya.

Dengan ketinggian antara 600-800 meter di atas permukaan laut, desa ini juga menawarkan pemandangan dengan lembah, bukit, dan danau sepanjang perjalanan.

\section{Area Perkebunan}

Selain itu, area perkebunan seperti kebun cengkeh, kopi, dan kakao juga tak kalah menarik untuk disaksikan. Memenuhi punggung bukit yang berbaris, hijaunya perkebunan yang dikelola warga setempat ini menjadi aksen yang pas untuk dinikmati melewati jalannya yang berkelok-kelok. Para pelintas juga tak jarang menemukan cengkeh atau biji kopi yang dijemur di pinggiran jalan hingga selintas tercium aroma menyegarkan dari kedua komoditas bernilai tinggi tersebut.

Ketiga komoditas mahal tersebut juga menjadi salah satu penghasilan utama bagi petani setempat dan memang terbukti memiliki mutu tinggi dan menjadi komoditi ekspor 
terutama ke Eropa. Perkebunan di desa ini luasnya hingga sekitar 1.000 hektar, sama dengan luas hutannya. Barulah di antara luasnya kebun dan hutan tersebut terdapat rumah-rumah warga, kebun, serta bangunan lainnya.

\section{Ada Kebun Warisan Belanda, Ada Air Terjun}

Desa Munduk memiliki sejarah yang kaya. Legenda mengatakan bahwa daerah itu dihuni oleh orang-orang dari pegunungan dan ada juga yang mengatakan beberapa klan datang dari Klungkung untuk bermukim di Desa Munduk pada sekitar 200 sampai 300 tahun yang lalu. Ketika Belanda memperluas kerajaan kolonial mereka dari Jawa ke Bali, mereka juga mencapai Bali selatan melalui Desa Munduk. Belanda juga membawa arsitektur kolonial ke Desa Munduk, bersama dengan komoditas ekspor tradisional seperti kopi, kakao, cengkeh dan vanili.

Seperti umumnya perkebunan di Indonesia, perkebunan di Munduk pun warisan Belanda. Sejak tahun 1900-an, ketika menjajahBali lewat Singaraja, Belanda sudah menjadikan Munduk dan desa-desa sekitarnya sebagai retreat atau tempat peristirahatan. Saat itu Singaraja adalah ibukota Provinsi Sunda Kecil. Bali termasuk di dalamnya. Di Munduk dan desa sekitarnya, seperti Banyuatis dan Gobleg, Belanda membangun guest house. Guest house pertama di Desa Munduk dibangun oleh Belanda pada 1908.

Wisata trekking menyusuri perkebunan warga, hutan dan mengunjungi beberapa spot menarik merupakan wisata andalan yang coba dikembangkan pengelola Desa Munduk. Kawasan yang menghijau dan berbukit-bukit dengan suhu berkisar $20-25^{\circ} \mathrm{C}$ tentu menggoda siapa saja yang menyukai petualangan, pengalaman baru ataupun menenangkan pikiran setelah melewati waktu panjang di tengah sumpeknya perkotaan. Udara sejuk dan medan yang menantang menjadi daya tarik tersendiri yang sungguh sayang untuk dilewatkan.

Wisata tracking merupakan solusi tepat dalam memanfaatkan potensi alam yang belum diketahui luas oleh banyak wisatawan yang berkunjung ke Desa Munduk, dimana kegiatan wisata tracking nantinya juga semakin terlihat menarik minat wisatawan, apabila kegiatan tersebut dipadukan dengan konsep Tri Hita Karana yang menjadi keunikan tersendiri, serta memberikan contoh kepada masyarakat lokal dan dampak wisata track- ing tersebut juga tentunya akan memberikan pengaruh positif terhadap masyarakat dan lingkungan. Wisata tracking juga akan meningkatkan perekonomian masyarakat desa itu sendiri, dikarenakan wisata tracking akan membuat waktu tinggal wisatawan di Desa Munduk semakin bertambah. Bertambahnya waktu tinggal wisatawan di Desa Munduk, tentunya akan berdampak kepada usaha-usaha masyarakat lokal dalam mendapatkan keuntungan.

Wisata tracking di Desa Munduk tersebut tentunya sudah memiliki sarana dan prasarana yang cukup baik, dimana akses jalur wisata tracking sudah dibuat oleh kelompok sadar wisata (DARWIS) yang dibentuk pada tahun 2003. Seiring berkembangnya pariwisata di Desa Munduk dibentuklah kelompok Giri Sutha yang terdiri dari perkumpulan guide lokal yang menjadi pemandu wisatawan mancanegara yang ingin melakukan kegiatan wisata tracking di Desa Munduk.

Dalam mencapai pasar sasarannya, paket wisata tracking yang akan dikemas tentunya harus memiliki saluran distribusi yang baik, sehingga produk wisata yang dihasilkan nantinya dapat dijual dan sampai kepada konsumen, yaitu wisatawan mancanegara. Adanya saluran distribusi yang baik diharapkan mampu memberikan efek positif terhadap kepariwisataan di Desa Munduk.

\section{Jalan Setapak}

Banyak jasa akomodasi wisata yang menawarkan paket trekking, baik dengan pemandu lokal ataupun tanpa pemandu. Bagi wisatawan lokal tentu akan lebih mengasyikkan untuk menyusuri sendiri kawasan ini tanpa kendala berarti karena warga setempat akan dengan senang hati melayani pertanyaan dan menunjukkan arah. Belum lagi banyak papan petunjuk yang tersebar di beberapa area untuk memudahkan perjalanan.

Salah satu spot menarik untuk dikunjungi adalah Air Terjun Melanting. Cukup mudah mencapainya karena kita tinggal mengikuti petunjuk yang terlihat jelas ketika menyusuri jalan raya sebelum diarahkan untuk memasuki jalan setapak di kawasan perkebunan. Meskipun cukup jalannya cukup nyaman, namun di beberapa titik kita akan menemui kondisi jalan berbatu yang curam dan licin karena lumut, hingga harus lebih berhati-hati agar tidak terpeleset. Kita juga harus berhati-hati dengan adanya lintah 
terutama di musim penghujan karena tanpa disadari akan menempel di kaki.

Berjalan kira-kira 20-30 menit, maka akan sampai di Air Terjun Melanting. Air terjun setinggi sekitar 200 meter ini dikelilingi tebing-tebing curam, sebelum jatuh di titik yang membentuk semacam 'kolam' di bawahnya sebelum mengalir ke sungai yang berarir jernih. Enaknya, kawasan air terjun ini terhitung sepi pengunjung hingga kita bisa menganggapnya sebagai 'milik sendiri', bebas berendam, saling bermain air ataupun bercanda sepuasnya dengan keluarga atau kolega yang kebetulan turut serta.

\section{Sumber Penghasilan}

Menurut Perbekel Desa setempat, Made Yasna, perkembangan pariwisata yang ada di Desa Munduk kian hari terasa kian menggembirakan jika mengacu pada manfaat yang didapatkan oleh penduduk sekitar. "Tentu ada manfaatnya, masyarakat sekitar jadi punya sumber penghasilan baru selain sebagai petani, kami pun melihat ini perlu adanya pembinaan-pembinaan lebih lanjut agar masyarakat semakin paham pengelolaan pariwisata yang baik," tutur Yasna sembari mengatakan pihaknya dalam waktu dekat akan mengadakan pelatihan pariwisata bagi warga setempat.

Sebagai gambaran, ia menyebut di Desa Munduk kini hampir tidak ada pengangguran karena pariwisata menyerap banyak tenaga kerja lokal. "Bahkan, mereka yang kerja di Denpasar banyak yang kembali lagi bekerja di Desa.

\section{Simpulan dan Saran \\ 1. Simpulan}

Dari hasil penelitian yang dilakukan dapat disimpulkan bahwa peranan desa wisata munduk di Desa Munduk Kecamatan Banjar Kabupaten Buleleng adalah sebagai sumber penghasilan bagi masyarakat di Desa
Munduk selain sebagai petani mengingat wilayah desa Munduk sebagai desa wisata yang banyak dikunjungi oleh wisatawan yang pada akhirnya dapat menambah penghasilan masyarakat sekitar.

\section{Saran}

Bagi pemerintah desa Munduk hendaknya dapat mendukung desa wisata di Munduk dengan membantu pemberian fasilitas pendanaan bagi pengembangan agar dapat berkembang. Selain itu masyarakat diberikan kemudahan untuk permodalan dalam rangka membangun usaha untuk mendukung desa wisata di desa Munduk Kecamatan Banjar Kabupaten Buleleng.

\section{DAFTAR PUSTAKA}

Nazir, M. 2003. Metode Penelitian. Jakarta: PT Ghalia Indonesia

Suharto, Edi. 2006. Membangun Masyarakat Memberdayakan Rakyat. Bandung: PT. Refika Aditama.

Cahyadi, B., dan Abdul K., (2015). "Peranan Tata Usaha Bagian Umum Kantor Bupati Deli Serdang dalam Meningkatkan Pelayanan", Jurnal Ilmu Pemerintahan dan Sosial Politik, 1 (1): 14-24

Pitana, I.G., dan Putu G.G. 2005. Sosiologi Pariwisata. Yogyakarta: Penerbit Andi.

Pendit, N.S. 2003. Ilmu Pariwisata, Sebuah Pengantar Perdana. Jakarta: Pradnya Paramita

Davey, K.J. 1998. Pembiayaan Pemerintahan Daerah, Praktek-Praktek Internasional dan Relevansinya Bagi Dunia Kerja. Jakarta: UI Press 